\title{
Development of national standards related to the integrated safety and security of high-rise buildings
}

\author{
Elena Voskresenskaya $^{1 *}$ and Lubov Vorona-Slivinskaya ${ }^{2}$ \\ ${ }^{1}$ Peter the Great Saint - Petersburg Polytechnic University, 195251, St. Petersburg, Polytechnicheskaya \\ str., 29, Russia \\ ${ }^{2}$ Federal State Budgetary Educational Institution of Higher Education «Saint Petersburg State \\ University of Architecture and Civil Engineering» (SPSUACE), St. Petersburg, 190005, Russia
}

\begin{abstract}
The article considers the issues of developing national standards for high-rise construction. The system of standards should provide industrial, operational, economic and terrorist safety of high-rise buildings and facilities. Modern standards of high-rise construction should set the rules for designing engineering systems of high-rise buildings, which will ensure the integrated security of buildings, increase their energy efficiency and reduce the consumption of resources in construction and operation.
\end{abstract}

\section{Introduction}

The Federal Law № 116-FZ of 21.07.1997 "On Industrial Safety of Hazardous Production Facilities" outlines the main tasks of the state policy in the field of ensuring the population safety and the protection of hazardous facilities. These tasks cover the following issues: development and legislative consolidation of technical regulations on safe operation and security of hazardous facilities; development of fundamental and applied science, technology and technics, including development and implementation in practice of information and forecasting and analytical systems; systems, means and methods of technical diagnostics of the installed service life of hazardous equipment; creation of systems for monitoring the status of hazardous facilities for assessment and operational prediction of the consequences of their destruction (damage); improvement of systems and facilities for the protection of hazardous facilities; ensuring the stable and safe operation of information and telecommunications systems of hazardous facilities; ensuring continuous monitoring of the condition of power supply systems and standby power sources at hazardous facilities. Since January 1, 2014, in accordance with clause 3 of Section 11 of the Federal Law of July 21, 1997 № 116-FZ, "organizations operating hazardous industrial facilities of a certain hazard class are required to create systems for managing the industrial safety of facilities and ensure their operation.

Current-day matters of administration and law in the field of high-rise construction were studied by the authors of this article [1] and in the works of other authors: Mir V. Ali [2],

\footnotetext{
${ }^{*}$ Corresponding author: elenvoskr@mail.ru
} 
Potapova Y. I. [3], Markov M. F. [4], Tour V., Markov M., Shcherbach A. [5], Telichenko V.V. [6].

\section{Experimental section}

A modern building or facility is a complex system, which includes a system of structures, engineering life support systems and systems of implementing resource and energy conservation processes, maintaining comfort and ensuring safety. All the systems that make up the building (facility) interact with each other and the environment. Safety-related buildings or facilities of the system (SRBF systems), interacting with the structures and volumes of the premises of the facility, with the equipment of engineering systems, the environment perform safety functions that lead to a reduction in the risk of harm to people, property and the environment. SRBF systems operate in a specific environment in interrelation with other systems. It is possible to assess the risks associated with the operation of these systems or to assess and confirm compliance only in each particular building (facility) with the connection to the terrain and taking into account local conditions. By this, systems related to the safety of buildings differ from systems, for example, related to the safety of machinery or vehicles.

SRBF systems include systems for monitoring the condition of bearing and enclosing structures of a building (facility), the ground of its foundation, the condition of the equipment of engineering systems, the state of the environment in the building (facility) and its surroundings; fire alarm systems, smoke and heat removal systems, burglar alarms, access control and management, television surveillance, sound systems for alarm purposes and other systems. These systems, being integrated into a single complex security system, simultaneously counteract many dangers arising from internal and external hazardous impacts of natural or man-caused nature on a building (facility) and its systems.

In accordance with the provisions of paragraphs 5.1 and 5.2 of the Manual International Organization for Standardization (ISO)/International Electrotechnical Commission (IEC) 51 and B.2 of IEC 61508-5, there is no absolute security, since after taking protective measures, residual risk remains. Considering security measures, it is possible only to talk about reducing the risk to a level that is acceptable to the population at a certain time in the certain country, taking into account the economic, social political situation, the existing traditions, and the benefits from the use of products. An acceptable risk is established resulting from finding a compromise between the interests of those who generate risks, those who are at risk, and the authorities that regulate relations between legal subjects and manage the resources of the country.

Bearing and enclosing structures and engineering equipment of a building (facility) create a favorable environment for people's life and activities, for the implementation of processes, and act as protection from the environment. At the same time, there remains some risk of harm caused by the behavior of structures and engineering systems under the influence of external and internal impacts of natural or man-caused nature. In order to reduce the risk degree, compensatory measures are taken with the use of electric, electronic, programmable electronic SRBF-systems. In case of not achieving the acceptable risk using SRBF systems, external risk reducing facilities can be additionally used. Among them, there are architectural forms, fencing or landscape solutions, which prevent, for example, unauthorized approach for vehicles to a building.

In modern SRBF systems, programmable electronic (PE) means are being increasingly used, the operation of which is controlled by the software and becomes an integral part of the SRBF systems. 


\section{Results}

High-rise buildings are new town-planning and functional-planning formations, formed along the vertical axis. However, a complex of town-planning requirements (solving transportation problems, providing objects of public service, gardening, etc.) is preserved, which should be met taking into account the spatial specifics of these objects. The Town Planning Code of the Russian Federation does not contain the term of high-rise building. There is the concept of a unique building, to which the objects of capital construction are referred with height of more than $100 \mathrm{~m}$ according to the design documentation.

Currently, the Worldwide Academy of Sciences of Complex Security and the University of Comprehensive Systems of Security and Engineering are developing seven basic national standards GOST R 53195 under the general title "Safety of functional systems associated with the safety of buildings and structures." The standard describes the measures (methods and/or means) for risk reduction and assessment methods established in GOST R 53195.3 and GOST R 53195.4 for SRBF systems and their components.

These standards developed for the first time cover all the necessary requirements for the full life cycle of a wide class of systems of any technological complexity used to ensure the safety of buildings and structures. Objects of standardization are means of automation and control systems, including fire-extinguishing means, firefighting equipment, other aspects of fire protection; alarm and warning systems; low-voltage switched equipment and control equipment, other switching equipment and control equipment.

A series of standards being developed will serve as a basis for newly developed and updated group standards and standards for individual safety systems and systems harmonized with international ISO and IEC standards.

The standards being developed do not have direct foreign analogs. For their development, the provisions of the IEC 61508-1 - IEC 61508-7, ISO 9000, ISO 9001, ISO 9004 standards are used.

The national standards under developing along with other national standards of this issue will enable providing a regulatory framework for the creation and application of modern security systems for a wide class of real estate, including highly dangerous, technically complex and unique objects; carrying out risk analysis and assessment, evaluating the completeness of safety and confirming compliance with the requirements of the technical regulations for the safety of buildings and structures; promoting the development of applied science, technology of information and forecasting and analytical systems and methods for diagnosing equipment of engineering systems and structures of buildings and facilities; promoting the improvement of systems and means of protection of buildings and facilities; ensuring the stable and safe functioning of information, telecommunication and control systems of protected objects; ensuring continuous monitoring of the condition of all systems of protected objects, including life supporting systems, energy and resource saving, process implementation, security and other systems; reducing the risk of harm to the life and health of citizens of the Russian Federation, property and the environment and/or reducing the severity of consequences in case of occurrence of hazardous events and reducing the costs of eliminating the consequences of emergencies; reducing technical barriers to international trade, including real estate trade; increasing the competitiveness of the security system products produced by domestic manufacturers on the Russian and international market.

\section{Discussion section}

Complex security of construction projects includes economic security. Certain indicators of economic security in construction should be considered. The dynamics of construction activity and the distribution of work scope in the construction sector in Russia are presented 
in Table 1.

Table 1. Distribution of work scope performed by type of activity "Construction" by federal districts, as $\%$ of the total

\begin{tabular}{lcr}
\hline & 2015 & 2016 \\
\hline The Russian Federation & $\mathbf{1 0 0}$ & $\mathbf{1 0 0}$ \\
Central Federal District & 27.6 & 25.8 \\
North-West Federal District & 13.1 & 14.5 \\
Southern Federal District & 8.4 & $7.7^{1)}$ \\
North-Caucasian Federal District & 4.3 & 4.4 \\
Volga Federal District & 20.0 & 19.6 \\
Ural Federal District & 11.6 & 11.6 \\
Siberian Federal District & 9.1 & 9.9 \\
Far Eastern Federal District & 5.8 & 6.5 \\
Crimean Federal District* & 0.1 & - \\
$*$ In accordance with the executive order of the President of the Russian \\
Federation № 375 "On the Southern Federal District" of July 28, 2016, the \\
Southern and Crimean Federal Districts were reorganized into the Southern \\
Federal District.
\end{tabular}

Over half of the construction work in 2016 was carried out in the following constituent territories of the Russian Federation: Moscow (11.5\% of the total work in Russia), St. Petersburg (6.7\%), Tatarstan (4.7\%), Bashkortostan (3.1\%), Krasnodar territory $(3.7 \%)$, Krasnoyarsk territory (3.2\%), Moscow Region (5.4\%), Nizhny Novgorod and Samara Regions (2.5\% each), Tyumen (without autonomous regions) $(2.6 \%)$, the Yamalo-Nenets Autonomous District (2.9\%) and the Khanty-Mansiysk Autonomous Region Ugra (2.8\%).

In the IV quarter of 2016, the results of surveys of business activity of construction companies indicate an unstable economic situation in the construction sector. The index of entrepreneurial confidence in the fourth quarter of 2016 was $-21 \%$, which is 8 percentage points lower than in the fourth quarter of 2015 and 5 percentage points lower than in the third quarter of 2016.

The increase in business activity in the IV quarter of 2016 was observed in 13 constituent entities of the Russian Federation. The results of the survey show that in 24 out of 82 subjects of the Russian Federation participating in the survey, the index of entrepreneurial confidence is higher than the average for Russia. Positive value of this indicator was noted in the Kaliningrad and Tver Regions. The lowest value of the index of entrepreneurial confidence $(-60 \%)$ is recorded in the Khabarovsk Territory.

The volume of investment in fixed capital for the development of construction activities in 2016 amounted to 445.0 billion rubles or $3.0 \%$ of the total volume of investments in fixed capital, which is $0.1 \%$ more than in 2015 .

In the total volume of investments aimed at developing their own base of construction organizations, the share of small businesses in 2016 was $28.2 \%$ compared to $29.9 \%$ in 2015 .

At the end of 2016, the full accounting value of fixed assets in construction amounted to 2233.9 billion rubles, or $1.3 \%$ of the value of fixed assets of all types of economic activity.

The commissioning of fixed assets by type of activity "Construction" amounted to 176.2 billion rubles, or $1,6 \%$ of the total volume of fixed assets introduced in the economy as a whole. Information on the level of depreciation of fixed assets in construction is presented in Table 2. 
Table 2. The level of deterioration, the coefficients of renewal and retirement of fixed assets in construction, \%

\begin{tabular}{lrrr}
\hline & 2014 & 2015 & 2016 \\
\hline $\begin{array}{l}\text { Coefficient of renewal of fixed assets (in } \\
\text { comparable prices) }\end{array}$ & 3.8 & 3.4 & 3.2 \\
$\begin{array}{l}\text { The coefficient of liquidation of fixed assets } \\
\text { (in comparable prices) }\end{array}$ & 1.1 & 1.0 & 1.0 \\
$\begin{array}{l}\text { Deterioration rate of fixed assets (in current } \\
\text { prices, at the end of the year) }\end{array}$ & 51.2 & 50.4 & 51.8 \\
\hline
\end{tabular}

The renewal coefficient of fixed assets in type of activity "Construction", calculated in comparable prices, in 2016 was $3.2 \%$ and decreased by 0.2 percentage points in comparison with 2015. The coefficient of retirement of fixed assets in construction in 2016 was $1.0 \%$ and did not change in comparison with 2015. In the last two years, the renewal coefficient of fixed assets in construction was slightly lower than in the economy as a whole, the retirement ratio was slightly higher, and the level of depreciation remains higher than the average for the economy. At the end of 2016 the degree of deterioration decreased by 1.4 percentage points as compared to 2015. The state of equipment as of 01.01.2016 is given in Table 3 .

Table 3. The presence and condition of the main construction machinery in construction companies

\begin{tabular}{|c|c|c|c|}
\hline & \multirow{2}{*}{$\begin{array}{r}\text { Total } \\
\text { amount, } \\
\text { thousand } \\
\text { units }\end{array}$} & \multicolumn{2}{|c|}{ Of total machinery amount, $\%$} \\
\hline & & $\begin{array}{r}\text { Machines with expired } \\
\text { service life }\end{array}$ & $\begin{array}{l}\text { Machines of } \\
\text { foreign } \\
\text { manufacture }\end{array}$ \\
\hline One-bucket excavators & 12.3 & 31.2 & 70.8 \\
\hline Tournapulls & 0.3 & 74.2 & 51.1 \\
\hline Vehicle-mounted cranes & 2.4 & 63.6 & 39.6 \\
\hline Pneumatic wheel-mounted cranes & 7.7 & 36.3 & 27.5 \\
\hline Caterpillar-tracked cranes & 1.5 & 42.8 & 53.1 \\
\hline Tower cranes & 4.1 & 46.6 & 26.1 \\
\hline Land levellers & 4.1 & 46.3 & 29.7 \\
\hline Tractors & 7.0 & 50.1 & 39.5 \\
\hline Bulldozer earthmovers & 9.3 & 46.7 & 40.9 \\
\hline
\end{tabular}

In 2016, the financial result of profitable organizations exceeded the financial result of unprofitable organizations by 130.6 billion rubles. In 2015 , the financial result of profitable organizations was lower than the financial result of unprofitable organizations by 54.3 billion rubles. Indexes of financial performance of construction organizations are presented (Tab. 4)

Table 4. Financial result of construction companies

\begin{tabular}{lrr}
\hline & 2015 & 2016 \\
\hline $\begin{array}{l}\text { Balanced financial result (profit minus loss), } \\
\text { million rubles }\end{array}$ & -54329 & 130560 \\
$\begin{array}{l}\text { In \% to the corresponding period of the previous } \\
\text { year }\end{array}$ & - & 139.5 \\
$\begin{array}{l}\text { The share of unprofitable organizations relative } \\
\text { to the total number of organizations, } \%\end{array}$ & 32.8 & 24.1 \\
$\begin{array}{l}\text { Amount of loss, million rubles } \\
\text { Profitability of sold goods, products, works and } \\
\text { services, \% }\end{array}$ & 320030 & 114424 \\
\end{tabular}

In 2016, about 900 construction companies were unprofitable. In 2016 the share of unprofitable organizations in the total number of construction organizations decreased by 8.7 
percentage points in comparison with 2015. In 2016 the profitability of sold goods, products, works and services increased by 1.7 percentage points in comparison with 2015 .

At the end of 2016 in organizations involved in construction activities, accounts payable exceeded receivables by 1195.4 billion rubles, or $43.6 \%$ (at the end of 2015 - by 1317.3 billion rubles or $52,4 \%$ ). At the end of 2016 , the share of overdue receivables in the total amount of accounts receivable in organizations engaged in construction activities was $4.5 \%$ and increased by 0.5 percentage points in comparison with the end of 2015 .

At the end of 2016, the share of overdue accounts payable in the total volume of accounts payable of these organizations was $2.3 \%$ and remained at the level of 2015 .

By end of 2016, overdue accounts payable of organizations engaged in construction amounted to 91.3 billion rubles, increased by $2.1 \%$ in comparison with the corresponding period of 2015, and overdue accounts receivable amounted 123.0 billion rubles, and increased by $22.2 \%$, respectively.

\section{Conclusions}

The Federal Autonomous Institution "Federal Center for Standardization, Technical Standardization and Compliance in Construction" has developed a set of rules for high-rise construction. It entered into force on February 2, 2017. The new set of rules "Engineering systems of high-rise buildings" covers the design of engineering systems for construction and reconstruction of public buildings higher than $55 \mathrm{~m}$ and residential buildings higher than 75 meters. The document sets the rules for the design of engineering systems of high-rise buildings, which will provide comprehensive security of buildings, increase their energy efficiency and reduce the consumption of non-renewable resources in construction and operation. Before the adoption of new rules, in order to build a facility above $100 \mathrm{~m}$, it was necessary to develop and adjust special regulations (SR), which restrained the development of high-rise construction. For 2017, the Ministry of Construction of Russia planned to develop a set of rules "High-rise buildings and complexes. Fire safety requirements".

Basic documents, firstly sets of rules for high-rise construction, began to function in 2017, but the complete number of documents that enable minimizing elaboration of various special regulations, will be developed within the period of 2017-2019.

\section{References}

1. E. Voskresenskaya, V. Snetkov Alexander Tebryaev and Zokhidjon Askarov V 2017 MATEC Web of Conferences 10608055

2. Mir V Ali V 2001 Electronic Journal of Structural Engineering 12-14 pp

3. Y I Potapova 2012 Progress of modern natural sciences 6 14-16 pp

4. M F Markov 2007 Architecture and construction $144-47 \mathrm{pp}$

5. T. Markov M Shcherbach A Architecture and construction, 2 72-81 pp (2008)

6. V. Telichenko High-rise construction, 2 112-122 (2008) 